\title{
Microbiological burden of public transport vehicles
}

\author{
Ayșe Seher Birteksöz Tan*, Gamze Erdoğdu \\ Department of Pharmaceutical Microbiology, Faculty of Pharmacy, İstanbul University, 34116, İstanbul, Turkey
}

Cite this article as: Birteksöz Tan AS, Erdoğdu G (2017). Microbiological burden of public transport vehicles. Istanbul J Pharm 47 (2): 52-56.

\begin{abstract}
The goal of this study was to determine the role of public transport in the transmission of microorganisms. A total of 60 swab samples were collected in the morning and evening from handles in public transport trams, metrobuses, and buses. Swab samples were examined using microbiological methods, and the number and types of microorganisms were determined. Total aerobic bacterial and fungal counts in samples collected in the evening were higher than those in samples collected in the morning from trams and metrobuses. However, the total bacterial and fungal counts were very high in samples collected in the morning and evening from buses. Staphylococcus aureus, coagulase-negative staphylococcus, and Enterococcus spp. were isolated from these samples. The results of our study show that public transportation can be a significant reservoir for spreading pathogenic microorganisms. For this reason, it is very important to regularly follow cleaning and hygiene rules and to inspect these vehicles.
\end{abstract}

Keywords: Microbiological burden, microbial contamination, public transport

\section{INTRODUCTION}

As part of living in society, many common spaces are shared with other people. This makes it possible to spread diverse microorganisms that can lead to infections. People who use public transport can pass bacteriological, virological, or fungal infections to other people (Rusin et al. 2002). The greatest risk for infectious diseases in these vehicles is that people sit close together in a closed environment and breathe the same air (Yatağan 1991; Furuya 2007; Edelson and Phypers 2011). These vehicles can become a significant source of microorganisms when passengers do not close their mouths when coughing and sneezing. Handles, seats, anchors, floors, and windows are areas that can host infectious microorganisms.

For this reason, detailed internal cleaning of public transportation vehicles, which thousands of people use every day, is an important issue. In İstanbul, public transport services are mainly run by İstanbul Electricity Tramway and Tunnel Businesses (IETT). According to IETT's official website, the institution serves in İstanbul with 4558 public and private buses and 334 metrobuses. The number of buses is about 5000, which means there are 3,440,000 passengers every day. IETT buses and other vehicles are reported to be cleaned to provide healthier environment for passengers (IETT 2015).

In our study, the microbiological burden of vehicles was evaluated in order to determine the role of public transportation vehicles in the transmission of microorganisms that can cause significant infections in humans.

\section{MATERIALS AND METHODS}

\section{Sample collection}

In this study, we investigated the microbiological burden of public transport such as trams, metrobuses, and buses, which are frequently used in daily life. A total of 60 samples were taken from the handles of these vehicles. Samples were taken from vehicles by morning and evening by swap method. 


\section{Swab method}

The samples were taken with swap, which is the popular testing method. In a 10×10 cm area, sampling was. Swaps were placed in a tube containing Amies agar gel transport media and brought to the laboratory for analysis.

\section{Microbiological analysis}

All the collected swap samples were analyzed to detect the presence of total bacterial and fungal count. The microbial species S. aureus, Pseudomonas aeruginosa, Escherichia coli, Salmonella sp. and Enterococcus sp. were investigated, as suggested in The United States Pharmacopeia (USP). Each sample was weighed aseptically and diluted in $\mathrm{pH} 7$ phosphate buffer and Tryptic Soy Broth (Difco). Serial dilutions of the samples were homogenized in phosphate buffer and spread on duplicate Tryptic Soy Agar (Difco) and Sabouraud Dextrose Agar (Difco). Plates were incubated at $37^{\circ} \mathrm{C} 48 \mathrm{~h}$ and $25^{\circ} \mathrm{C}$ 5-7 days. At the end of the incubation, emergent colonies were counted and the numbers of colony forming units (CFU/ml) were determined. Tryptic Soy Broth was incubated at $37^{\circ} \mathrm{C} 24 \mathrm{~h}$. After incubation, samples were spread on Mannitol Salt Agar (Oxoid), Baird-Parker Agar (Difco), Cetrimide Agar (Difco), MacConkey Agar (Difco), Eozine Methylene Blue Agar (Difco), Fluid Tetra- thionate Medium (Difco), Xylose-Lysine Deoxycholate Agar (Difco), Bismuth Sulfite Agar (Difco) and Enterococcosel Agar (Difco) to determine the presence of specific microorganisms according to pharmacopeia (USP 2009). Plates were incubated at $37^{\circ} \mathrm{C} 24 \mathrm{~h}$ and identification was performed after microscopic examination and biochemical identification.

\section{RESULTS}

\section{Microbiological analysis}

Sixty samples taken from the handles belonging to 10 different trams, metrobuses and buses in the morning and evening were microbiologically examined.

\section{Determination of total aerobic bacteria and fungus numbers in the samples belonging to the trams and the isolated microorganisms}

A total number of bacteria and fungi counts and isolates determined in the samples belonging to the trams in the morning and evening were summarized in Tables 1 and 2. The total number of bacteria for one of the samples taken in the morning, the total number of bacteria in the eight samples taken in the evening and the total number of fungi in one sample were found high.

Table 1. The total aerobic bacteria, fungi counts and isolated microorganisms in the samples taken from the trams in the morning

\begin{tabular}{|c|c|c|c|c|}
\hline $\begin{array}{l}\text { Sample } \\
\text { Area }\end{array}$ & $\begin{array}{l}\text { Sample } \\
\text { No }\end{array}$ & $\begin{array}{l}\text { Total Bacterial Count } \\
\text { (cfu/mL) }\end{array}$ & $\begin{array}{l}\text { Total Fungal Count } \\
\text { (cfu/mL) }\end{array}$ & $\begin{array}{c}\text { Isolated } \\
\text { Microorganisms }\end{array}$ \\
\hline \multirow{10}{*}{ Handles } & 1 & - & - & - \\
\hline & 2 & $2 \times 10^{1}$ & $3 \times 10^{1}$ & KNS \\
\hline & 3 & $<1 \times 10^{1}$ & - & Enterococcus spp, KNS \\
\hline & 4 & - & - & KNS \\
\hline & 5 & $1 \times 10^{1}$ & - & S.aureus \\
\hline & 6 & - & - & KNS \\
\hline & 7 & $6.28 \times 10^{5}$ & - & - \\
\hline & 8 & - & $2 \times 10^{1}$ & - \\
\hline & 9 & $6 \times 10^{1}$ & - & KNS \\
\hline & 10 & $5 \times 10^{1}$ & - & Enterococcus spp \\
\hline
\end{tabular}

Table 2. The total aerobic bacteria, fungi counts and isolated microorganisms in the samples taken from the trams in the evening

\begin{tabular}{|lcccc|}
$\begin{array}{l}\text { Sample } \\
\text { Area }\end{array}$ & $\begin{array}{c}\text { Sample } \\
\text { No }\end{array}$ & $\begin{array}{c}\text { Total Bacterial Count } \\
\text { (cfu/mL) }\end{array}$ & $\begin{array}{c}\text { Total Fungal Count } \\
\text { (cfu/mL) }\end{array}$ & $\begin{array}{c}\text { Isolated } \\
\text { Microorganisms }\end{array}$ \\
\hline 1 & $2.8 \times 10^{3}$ & - & - \\
& 2 & $3.4 \times 10^{2}$ & $1.34 \times 10^{3}$ & S.aureus \\
S.aureus & - \\
Handles & $1.83 \times 10^{3}$ & $2.5 \times 10^{1}$ & - \\
& 4 & - & $1 \times 10^{1}$ & - \\
& 5 & $1.14 \times 10^{3}$ & - & - \\
Enterococcus spp, & - \\
& 7 & $2.2 \times 10^{2}$ & - & - \\
\end{tabular}




\section{Determination of total aerobic bacteria and fungus numbers in the samples belonging to metrobuses and the isolated microorganisms}

A total number of bacteria and fungi counts and isolates determined in the samples belonging to the metrobus in the morning and evening were summarized in Tables 3 and 4 . Eight of the samples taken in the morning and seven of the samples taken in the evening were found to have a high total number of bacteria.

\section{Determination of total aerobic bacteria and fungus numbers in the samples belonging to buses and the isolated microorganisms}

A total number of bacteria and fungi counts and isolates determined in the samples belonging to the buses in the morning and evening were summarized in Tables 5 and 6 . The total number of bacteria in the six samples taken in the morning and the total number of fungi in one sample were found to be high. The total number of bacteria and fungi in the all samples taken in the evening were also high.

\section{DISCUSSION}

Public transportation vehicles facilitate the spread of various pathogens that can cause frequent infections in the com- munity. These vehicles are vectors of colds, flu, and bronchitis in winter months. Many public transport vehicles carry passengers well above their capacity, especially in the morning and evening hours. This leads to the spread of disease among people using these vehicles. To ensuring proper hygiene, these vehicles must be inspected regularly.

Hand-touch sites can become contaminated with bacteria and become fomites for the transmission of bacteria between humans. Such sites can provide a reservoir for community-associated bacteria in high-prevalence areas [Brook and Brook (1994); Rusin et al. (2002); Simoes et al. (2011); Zhou and Wang (2013)]. Stepanovic et al. (2008) recently reported a high frequency of methicillin-resistant, coagulase-negative staphylococci but no MRSA contaminating hand-touch sites on public transportation vehicles in Serbia (Stepanovic et al. 2008). Otter and French determined total aerobic counts in 118 hand-touch surfaces on buses, trains, stations, hotels, and public areas of a hospital in central London. S. aureus isolates were identified (Otter and French 2012).

According to the information provided by the IETT General Directorate, vehicles that serve millions of people every day have a detailed interior and exterior cleaning to provide a more healthy environment for the passengers. It is stated that these

Table 3. The total aerobic bacteria, fungus counts and isolated microorganisms in the samples taken from the metrobuses in the morning

\begin{tabular}{|ccccc}
$\begin{array}{l}\text { Sample } \\
\text { Area }\end{array}$ & $\begin{array}{c}\text { Sample } \\
\text { No }\end{array}$ & $\begin{array}{c}\text { Total Bacterial Count } \\
\text { (cfu/mL) }\end{array}$ & $\begin{array}{c}\text { Total Fungal Count } \\
\text { (cfu/mL) }\end{array}$ & $\begin{array}{c}\text { Isolated } \\
\text { Microorganisms }\end{array}$ \\
\hline 1 & $5.1 \times 10^{4}$ & - & - \\
& 2 & $6.25 \times 10^{5}$ & - & KNS \\
Handles & 3 & $3.6 \times 10^{5}$ & - & Enterococcus spp, KNS \\
& 4 & $4.26 \times 10^{5}$ & - & KNS \\
& 5 & $3.83 \times 10^{5}$ & - & KNS \\
& 6 & $2.6 \times 10^{4}$ & - & KNS \\
& 7 & $5.42 \times 10^{5}$ & - & - \\
& 8 & $6.25 \times 10^{6}$ & - & S.aureus \\
& $4.10^{1}$ & - & S.aureus
\end{tabular}

Table 4. Total aerobic bacteria, fungus counts and isolated microorganisms in the samples taken from the metrobuses in the evening

\begin{tabular}{|c|c|c|c|c|}
\hline $\begin{array}{l}\text { Sample } \\
\text { Area }\end{array}$ & $\begin{array}{c}\text { Sample } \\
\text { No }\end{array}$ & $\begin{array}{l}\text { Total Bacterial Count } \\
\text { (cfu/mL) }\end{array}$ & $\begin{array}{l}\text { Total Fungal Count } \\
\text { (cfu/mL) }\end{array}$ & $\begin{array}{c}\text { Isolated } \\
\text { Microorganisms }\end{array}$ \\
\hline \multirow{10}{*}{ Handles } & 1 & $3.22 \times 10^{5}$ & - & KNS \\
\hline & 2 & $8.21 \times 10^{4}$ & - & KNS \\
\hline & 3 & - & $2 \times 10^{1}$ & KNS \\
\hline & 4 & $7.11 \times 10^{5}$ & - & KNS \\
\hline & 5 & - & - & KNS \\
\hline & 6 & $2.64 \times 10^{5}$ & $2 \times 10^{1}$ & KNS \\
\hline & 7 & - & - & KNS \\
\hline & 8 & $3.24 \times 10^{5}$ & - & KNS \\
\hline & 9 & $6.14 \times 10^{5}$ & - & KNS \\
\hline & 10 & $2.13 .10^{5}$ & - & KNS \\
\hline
\end{tabular}


Table 5. The total aerobic bacteria, fungus counts and isolated microorganisms in the samples taken from the buses in the morning

\begin{tabular}{|c|c|c|c|c|}
\hline $\begin{array}{l}\text { Sample } \\
\text { Area }\end{array}$ & $\begin{array}{l}\text { Sample } \\
\text { No }\end{array}$ & $\begin{array}{l}\text { Total Bacterial Count } \\
\text { (cfu/mL) }\end{array}$ & $\begin{array}{l}\text { Total Fungal Count } \\
\text { (cfu/mL) }\end{array}$ & $\begin{array}{c}\text { Isolated } \\
\text { Microorganisms }\end{array}$ \\
\hline \multirow{10}{*}{ Handles } & 1 & $2.6 \times 10^{2}$ & - & S.aureus \\
\hline & 2 & $3 \times 10^{1}$ & - & Enterococcus spp, \\
\hline & 3 & $1.2 \times 10^{2}$ & - & Enterococcus spp, KNS \\
\hline & 4 & $1.3 \times 10^{2}$ & - & Enterococcus spp,KNS \\
\hline & 5 & $1 \times 10^{1}$ & - & Enterococcus spp, KNS \\
\hline & 6 & $7 \times 10^{1}$ & - & Enterococcus spp, KNS \\
\hline & 7 & $4 \times 10^{1}$ & - & Enterococcus spp, KNS \\
\hline & 8 & $1.8 \times 10^{4}$ & - & Enterococcus spp, KNS \\
\hline & 9 & $5.6 \times 10^{2}$ & - & Enterococcus spp, KNS \\
\hline & 10 & $9 \times 10^{2}$ & $1.7 \times 10^{3}$ & Enterococcus spp, KNS \\
\hline
\end{tabular}

\section{Table 6. The Total aerobic bacteria, fungus counts and isolated microorganisms in the samples taken from the buses in the evening}

\begin{tabular}{|c|c|c|c|c|}
\hline $\begin{array}{l}\text { Sample } \\
\text { Area }\end{array}$ & $\begin{array}{c}\text { Sample } \\
\text { No }\end{array}$ & $\begin{array}{l}\text { Total Bacterial Count } \\
\text { (cfu/mL) }\end{array}$ & $\begin{array}{l}\text { Total Fungal Count } \\
\text { (cfu/mL) }\end{array}$ & $\begin{array}{c}\text { Isolated } \\
\text { Microorganisms }\end{array}$ \\
\hline \multirow{10}{*}{ Handles } & 1 & $3.83 \times 10^{5}$ & $2.6 \times 10^{2}$ & S.aureus \\
\hline & 2 & $3.14 \times 10^{5}$ & $3.2 \times 10^{2}$ & S.aureus \\
\hline & 3 & $6.81 \times 10^{4}$ & $1.3 \times 10^{2}$ & Enterococcus spp, S.aureus \\
\hline & 4 & $7.11 \times 10^{5}$ & $1.5 \times 10^{2}$ & S.aureus \\
\hline & 5 & $1.24 \times 10^{4}$ & $1.4 \times 10^{2}$ & S.aureus \\
\hline & 6 & $2.4 \times 10^{6}$ & $3.25 \times 10^{4}$ & Enterococcus spp, S.aureus \\
\hline & 7 & $1.3 \times 10^{4}$ & $1.09 \times 10^{2}$ & S.aureus \\
\hline & 8 & $7.1 \times 10^{5}$ & $6.1 \times 10^{5}$ & S.aureus \\
\hline & 9 & $3.25 \times 10^{4}$ & $1.37 \times 10^{4}$ & S.aureus \\
\hline & 10 & $1.71 \times 10^{5}$ & $1.59 \times 10^{2}$ & S.aureus \\
\hline
\end{tabular}

routine cleanings are carried out every day by 4:00 am as the vehicles are readied for morning service. It is also stated that the vehicles are subjected to detailed disinfection treatment once a week, thus making the vehicles safe from microbiological contamination (IETT 2015).

When we compared the results of the samples taken in morning and evening by public transportation vehicles, it was determined that the samples taken in the evening from all vehicles were much higher than the counts of the samples taken in the morning for aerobic bacteria and fungus counts.

In particular, the total aerobic bacteria counts of the samples taken in the morning from the buses were high so daily cleaning procedures were insufficient. In addition, the isolation of pathogens such as S. aureus, Staphylococcus and Enterococcus in the specimens shows that these vehicles may be important sources of infection.

The presence of S. aureus in these vehicles is of great importance for both hospital-acquired and community-acquired infections. Transmission is usually through direct contact or droplet contact. In humans, skin inflammation can lead to various organ infections such as wound infections, urinary tract infections, pneumonia or poisoning (Bilgehan 1992; Gürler 2008; Winston and Chambers 2009). Enterococci are among the leading endocarditis agents and may cause various infections such as bacteremia, salpingitis, endometritis, peritonitis, biliary tract infections, intraabdominal abscess, and sometimes meningitis (French 2010)

We have found that the microbial load in public transportation vehicles is high. It has also been shown that these vehicles can be an important source of contamination for many community-based infections. Our results suggest that these vehicles need to be cleaned, disinfected and tested more often. In addition, those who use these vehicles could prevent many diseases with proper hand washing techniques.

\section{REFERENCES}

- $\quad$ Bilgehan H (1992). Klinik Mikrobiyoloji Özel bakteriyoloji ve Bakteri Infeksiyonları. Barış Yayınları Fakülteler Kitabevi, İmir.

- Brook J, Brook I (1994). Recovery of organisms from the handrails of escalators in the public metro rail system in Washington, D.C. J Environ Health 57: 13-14.

- $\quad$ Edelson PJ, Phypers M (2011). TB transmission on public transportation: a review of published studies and recommendations for contact tracing. Travel Med Infect Dis 9: 27-31. [CrossRef] 
Istanbul J Pharm 47 (2): 52-56

- Furuya H (2007). Risk of transmission of airborne infection during train commute based on mathematical model. Environ Health Prev Med 12: 78-83. [CrossRef]

- French $G L$ (2010). The continuing crisis in antibiotic resistance. Int $J$ Antimicrob Agents 36: 3-7. [CrossRef]

- Gürler B (2008). Istanbul Üniversitesi Tip Fakültesi Tibbi Mikrobiyoloji-3: Nobel Kitabevleri, İstanbul.

- İstanbul Elektrik Tramvay ve Tünel İşletmeleri Genel Müdürlüğü (IETT), Internet Sitesi http://www.iett.gov.tr.

- Otter JA, French GL (2012). Community-associated meticillinresistant Staphylococcus aureus: the case for a genotypic definition. J Hosp Infect 81: 143-148. [CrossRef]

- Rusin P, Maxwell S, Gerba C (2002). Comparative surface-to-hand and fingertip-to-mouth transfer efficiency of gram-positive bacteria, Diversity of Staphylococcus spp. in public transit 207 gram-negative bacteria, and phage. J App/ Microbio/ 93: 585-592. [CrossRef]
Simoes RR, Aires-de-Sousa M, Conceicao T, Antunes F, Martins da Costa P Lencastre H (2011). High prevalence of EMRSA-15 in Portuguese public buses: a worrisome finding. PLoS One 6: 1-5. [CrossRef]

Stepanovic S, Cirkovic I, Djukic S, Vukovic D, Svabic-Vlahovic M (2008). Public transport as a reservoir of methicillin-resistant staphylococci. Lett Appl Microbio/ 47: 339-341. [CrossRef]

- $\quad$ USP 32- NF 27. (2009) Microbial Limit Tests. The United States Pharmacopeia.

- Winston LG, Chambers HF (2009). Antimicrobial resistance in Staphylococci: Mechanisms of resistance and clinical implications. Mayers D, (ed). Antimicrobial Drug Resistance Mechanisms of Drug Resistance. Vol.1, Humana Press, pp. 735-748. [CrossRef]

- Yatağan E (1991) Bulaşıcı Hastalıklar ve Epidemiyoloji. 2. Baskı, Sekav, İstanbul.

- Zhou F, Wang Y (2013). Characteristics of antibiotic resistance of airborne Staphylococcus isolated from metro stations. Int J Environ Res Public Health 10: 2412-2426. [CrossRef] 